\title{
Why a New Journal on Regenerative Medicine?
}

\section{Daniel Moya ${ }^{1}$}

"Strange times are these in which we live, when old and young are taught falsehoods in school. And the person that dares to tell the truth is called at once a lunatic and fool." It sounds current, however, it was stated by Plato almost 2400 years ago.

Obviously, the collision between old and new ideas, different points of view, and scientific approaches has always been conflictive. In our times this situation is exacerbated by the enormous generation of information and by the indiscriminate access to it.

Educational offer includes scientific societies, universities, predatory editors, industry, and even beginners, who simply by having access to social media become opinion makers. The tenuous limits between scientific information, marketing, and entertainment have their maximum expression in the field of social media.

What can we do? The answer also comes from the golden age of Greece: The scientific method. Its basis is the search for truth. The truth cannot be modified by biases.

The findings of observation and experimentation should be disseminated.

Despite isolated initiatives, there has not been a coordinated effort or an editorial forum dedicated to techniques such as the use of mechanical waves in non-invasive regenerative medicine. That is the reason of this publication. This Journal will also include information on minimally invasive, and invasive techniques as long as they are related to tissue regeneration.

Any applied treatment has no value if it is not based on a precise diagnosis, so it will also be of interest to this Journal to include not only therapeutic concepts but also the discussion of the diagnostic criteria and the most commonly used complementary tests.

The heart and soul of a publication are the authors. I will be eternally grateful to them for trusting in this project and enthusiastically joining this first issue.

The circuit will be completed with readers, their opinion and contribution will be valued. We will develop a section dedicated to this. Interaction with the readers will surely give the publication more dynamics and enrich it.

It would have been impossible to make this initiative a reality without the encouragement and trust of Dr. Ashok Shyham Pasi, the technical and scientific contribution of The Indian Orthopedic Research Group, the support of the Ibero Latin American Federation of Shockwaves and Tissue Engineering, and the editing input of Ms. Kajal Mandalia.

If we manage to improve the practice of a colleague or benefit the quality of life of a patient anywhere in the world, our mission will be fulfilled.
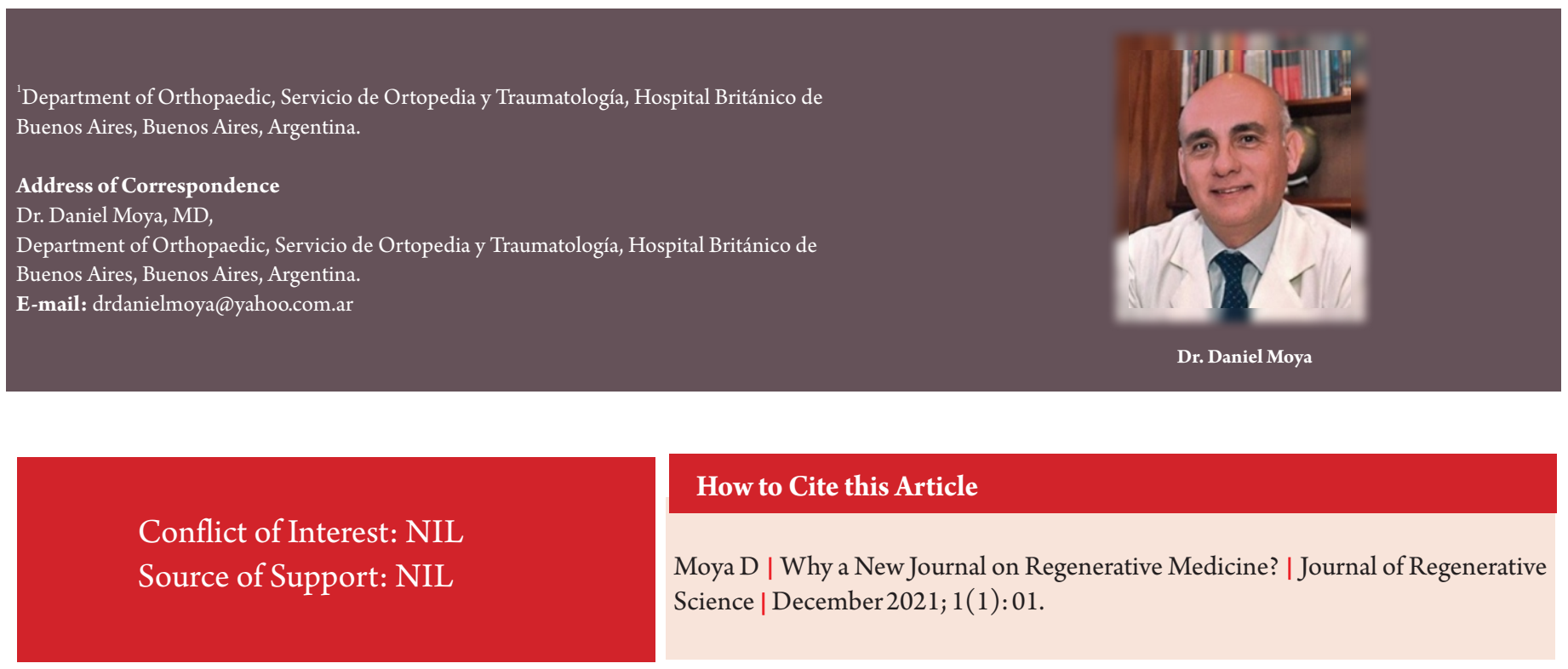

\section{How to Cite this Article}

Moya D | Why a New Journal on Regenerative Medicine? | Journal of Regenerative Science | December 2021; 1(1):01.

Submitted Date: 30 April 2021, Review Date: 21 May 2021, Accepted Date: 28 May 2021 \& Published: 31 December 2021

(C) 2021 by Journal of Regenerative Science | Available on www.jrsonweb.com | DOI:10.13107/jrs.2021.v01.i01.003

This is an open access journal, and articles are distributed under the terms of the Creative Commons Attribution-NonCommercial-ShareAlike 4.0 License (https://creativecommons.org/licenses/by-nc-sa/4.0/), which allows others to remix, tweak, and build upon the work non-commercially, as long as appropriate credit is given and the new creations are licensed under the identical terms. 